\title{
The Potential of Residual Processing of Indonesian Marine and Coastal Areas as Biogas Energy
} \author{
Siregar $^{3}$, and Lebrina Ivantry Boikh ${ }^{4}$ \\ ${ }^{1}$ Fisheries Mechanization, Marine and Fisheries Polytechnic of Kupang, Indonesia \\ ${ }^{2}$ Computer System Engineering, STMIK STIKOM Indonesia, Indonesia \\ ${ }^{3}$ Fishing Technology, Marine and Fisheries Polytechnic of Kupang, Indonesia \\ ${ }^{4}$ Faculty of Marine and Fisheries, Nusa Cendana University, Indonesia \\ ${ }^{*}$ Corresponding author. Email: made.nugraha@kkp.go.id
}

I Made Aditya Nugraha ${ }^{1, *}$, I Gusti Made Ngurah Desnanjaya², Jhon Septin M

\begin{abstract}
Indonesia's marine and fisheries products are enormous. This potential certainly results in the production of catch and cultivation, which is so large and indirectly affects the processing activities. The amount of processing activity seen from the existing potential of $6,181,997.48$ tons per year is estimated to produce the remaining processing results of 1,693,697.94 kg per day. The remaining results of this processing can of course, be used as a source of biogas energy to produce electrical energy. The aim of this study is to determine the potential of biogas energy from the processing residue which has such great potential as electrical energy. The potential remaining processing estimates that it can produce as much as $8,468,489,700 \mathrm{~m}^{3}$ of Biogas per day with the potential for electrical energy that can be utilized as much as $51.66 \mathrm{MWh}$ per day or $1549.73 \mathrm{MWh}$ per month. This potential will greatly help the electrical energy needs of coastal communities and reduce the use of fossil energy. This activity is also a form of support for the use of renewable energy and environmental conservation, especially the marine and fishery environment.
\end{abstract}

Keywords: Biogas, Renewable energy, Fish industry waste, Fishery

\section{INTRODUCTION}

As one of the largest maritime countries, Indonesia has tremendous natural resource potential. Development in the marine and fisheries sector is one of the economic sectors that has always been positioned as a fringe sector in national economic development. This incident is ironic considering that our country is known as the world's largest maritime and archipelagic state. This wealth is composed of approximately 13,000 islands and is united by a sea of 6.4 million $\mathrm{km}^{2}$ (including EEZ) [1][2][3][4].

The development of civilization has changed the pattern of human civilization. Still, it has also changed the mindset and utilization of marine and fishery resources from just-food needs to a way of life and economic needs. In the fisheries and marine sector, the economic potential of the resources owned is quite significant. It has a vital role in national economic development, especially in providing protein foods, earning foreign exchange, and providing employment opportunities. With the support of the sea area of 5.8 million square kilometers, it is estimated that it has an excellent opportunity to encourage economic recovery. Potential resources can come from capture fisheries, marine aquaculture, marine biotechnology, and aquaculture. This abundant wealth does not include marine products such as seaweed, pearls, and shellfish.

Data from FAO in 2018 on the Impact of Climate Change on Fisheries and Aquaculture over the last few decades, an increase in marine capture fisheries production was carried out by developing countries (from 29\% in the 1950s to 71\% in 2016). In 2016, Asian countries became the leading producers by $54 \%$, and Indonesia became the $2^{\text {nd }}$ with the most prominent producer after China. For aquaculture, China, India, and Indonesia accounted for $75 \%$ of global aquaculture production in 2016. Based on data from the Ministry of Maritime Affairs and Fisheries (2020), aquaculture 
production is superior to marine capture fisheries or inland public water capture fisheries. The Indonesian Fishery Subsector Farmer's Exchange Rate (Nilai Tukar Petani Subsektor Perikanan/ NTP) cannot be underestimated. This activity resulted in excellent economic activity. The average NTP of the Fisheries Subsector, which consists of capture fisheries and aquaculture, continues to increase. The increase in the index received (It) is higher than the increase in the index paid (Ib). The increase in the received index (It) from 121.69 in 2015 to 137.7 in 2018 . At the same time, the paid index $(\mathrm{Ib})$ increased more slowly from 118.86 in 2015 to 129.92 in 2018. According to Bappenas (2013), the most considerable contribution of The high price index received by farmers in the fishery sub-sector stems from the high price of fishing products [3][4][5].

If we look specifically at the NTP of the Capture Fisheries Sub-sector, the NTP value is profitable, at 113.74, the national average in 2019. However, this value varies between regions in Indonesia. The higher the NTP number indicates, the better the economic condition of the fishing fishermen. Unfortunately, this condition is not evenly distributed throughout Indonesia. There are still many areas where the NTP is in the range of 100 , meaning that the difference in the index received and paid by farmers is thin. The profits from fishing are only slightly more than the costs incurred. Regions with high fish production with NTP above the national average are concentrated in the provinces around WPPNRI 573, WPPNRI 711, WPPNRI 712, WPPNRI 713.

Bappenas (2014) mentions that although there has been an increase in catch production, the development of capture fisheries still faces many obstacles, namely the increasingly limited availability of fish resources. Indonesia's fisheries problems include Illegal, Unregulated, and Unreported (IUU) fishing and overfishing. The number of catches close to the Maximum Sustainable Yield (MSY) causes a slowdown in production growth.

Fish products are a substantial source of animal protein in Indonesia. Based on BPS data (2020), the average calorie consumption from fisheries is $49.89 \mathrm{kcal}$ per capita per day, and protein is $8.43 \mathrm{kcal}$ per capita per day. In addition to domestic consumption, in 2019, Indonesia exported 1.18 thousand tons of fishery products with an export value of US\$ 4.94 billion. Fishery products also contributed 419,982 billion rupiahs to Indonesia's Gross Domestic Product or $2.65 \%$ of total GDP. This condition makes the fishery sector have an important role socially and economically for the people of Indonesia. However, the sustainability of fisheries, especially the capture fisheries sub-sector, needs attention mainly because capture fisheries take directly from nature and are affected by changes in natural conditions due to climate change.
As an approach to the description of coastal communities, seaside village data is obtained from the Village Potential Income (Pendapatan Potensi Desa/ PODES). Several aspects were studied in terms of the economic structure of the village, social elements, and pollution in seaside villages. In 2011, there were 11,884 coastal villages (15.12 percent), in 2014 , there were 12,827 (15.61 percent), and in 2018 there were 12,857 villages $(15.32$ percent $)$ of the total villages in Indonesia.

Data collection on Village Potential in 2014 and 2018 shows changes in most villagers' main source of income. In 2014 the main income of 90.42 percent of seaside villages was in the agricultural sub-sector, including fisheries, but in 2018 it was reduced to 89.38 percent of villages. At the same time, it can be seen that the percentage of seaside villages with the main income from processing and trading industries has increased. The increase in villages with the main income in the trade sector was 0.92 percent to 3.69 percent of villages and villages with the main income from the processing industry by 0.54 percent to 1.88 percent of villages.

As an illustration, small and micro-scale industries that develop in seaside villages are the food and beverage industry, which is in 5,845 (45.46 percent) seaside villages, and the wood industry, which is found in 5,608 (43.62 percent) seaside villages. Furthermore, woven and cloth industries were found in 19.32 percent and 18.09 percent of seaside villages. As for trading facilities, almost all villages have grocery stores/warung (92.13 percent), and about 48.69 percent of coastal villages have food and beverage stalls/shops. Lodging is available in 1,471 villages (11.44 percent) seaside villages. The number of seaside villages according to the presence of small/micro industries and the existence of trade facilities and hotels.

In general, byproducts are leftovers from a business and/or human activity in the form of solid, liquid or gas which are deemed to have no economic value and therefore tend to be discarded. Byproducts can mean the unused part of a production process, both industrial and domestic (household), whose presence at a particular time and place is not desired by the environment because it does not have economic value. Fishery waste/byproducts are fish that are wasted, scattered, and processed residues which at one time in a certain place and cannot be used economically.

Shrimp and fish-catching business activities continue to increase. The business activity of catching shrimp and fish using shrimp trawls and fish trawls continues to rise in Eastern Indonesia (Kawasan Timur Indonesia). About $82 \%$ of the by-catch of the total catch is dumped into the sea, and only a small part is utilized. The proper utilization of legal byproducts of catch will certainly increase cost efficiency and increase fishermen's income. The average byproduct produced 
from fishing activities is around 20-30 percent, which, if not appropriately used will pollute the environment.

Through a blue economy approach which is based on one of the principles of zero waste (without waste), marine and fisheries activities are emphasized on activities that process all waste (byproducts) of production into inputs for other activities, in other words, the waste produced becomes an input for other production activities. On this side, innovation in all things is needed. On the product side, there are innovations in processing waste/byproducts into inputs for other processes. The expected result is that byproducts can be utilized into value-added products that will contribute to employment, business sustainability, and environmental sustainability [6][7][8][9][10][11].

One form of waste management byproducts from fish processing is that it can be used as electrical energy. This electrical energy is a system of generating electrical energy sourced from Biogas. This potential opportunity might help the lives and electrical energy needs of coastal communities in Indonesia [12][13][14] [15][16]. The results of this study are expected to be developed again with current technological advances [17][18][19][20]. One of these technologies is a control system, where this system can regulate and monitor the process and results of Biogas.

\section{RESEARCH METHODS}

This research is descriptive and is a study in finding the potential of biogas energy sourced from the rest of the processing of marine and fishery products. This study will be a reference and material for further studies on the potential of Biogas from marine and fisheries products, which are so prominent in Indonesia. This paper attempts to review the availability of the system and its use for coastal communities. The availability discussed in this paper is about the potential and capacity of the system to be installed. The data presented in this paper were obtained from publications, manufacturers, relevant government departments, scientific publications, and other publications. Information about the use of Biogas as a source of electrical energy is expected to be a quick reference for community members, especially fishermen who are interested in utilizing biogas energy as a source of electrical energy to develop renewable and environmentally friendly power plants.

In infield activities, some organic materials that can be used as Biogas are mixed with other materials to increase and regulate the $\mathrm{C} / \mathrm{N}$ Ratio. The $\mathrm{C} / \mathrm{N}$ Ratio is calculated following the formula [16]:

$C / N$ Ratio $=C / N$

Total TS $=$ TS $(\%) \times$ Total Organic Matter $(\mathrm{kg})$
To find out the amount of gas produced per day, it can be calculated by the following formula.

Total TS $(\mathrm{kg}) \times \mathrm{Gas}$ Production $\left(\mathrm{m}^{3}\right)$

The amount of potential electrical energy is calculated following the formula. In $1 \mathrm{~m} 3$ of Biogas is equivalent to $6.1 \mathrm{kWh}$ of electrical energy.

Electrical Energy = Gas Production $\left(\mathrm{m}^{3}\right) \times$ Biogas Energy $(k W h)$

The amount of electrical energy that can be generated for each unit per unit time is calculated using the following formula.

$W=P_{X} H$

\section{RESULTS AND DISCUSSION}

Fish is a product that is very easily damaged or undergoes changes in quality (degradation in quality perishable food). Since the fish is removed from the water, a series of quality deterioration occurs and makes its appearance, smell, and taste change worsen and reduce its economic value. These changes happen very quickly, depending on the type, size, and shape of the fish, temperature, and environmental conditions of the fish.

The characteristics of the byproducts of fishery activities produced can be analogous to having the same features. The protein and water content which is still relatively high is certainly suitable as a medium for the growth of spoilage bacteria or other microorganisms. The urea content is relatively high in fishery products, and if not handled immediately, it will decompose into ammonia compounds, giving an unpleasant aroma.

The byproducts produced from fishery activities can generally be grouped into four groups, such as:

1. Byproducts of catching a species or resource, for example, trash fish in shrimp capture and tuna fishing;

2. Part of fish which is not utilized by fish processing business, among others: surimi processing industry, canning industry, or milling industry;

3. Fish that are not absorbed by the market, especially during the season of abundant fish production (surplus from catch); and

4. Error handling and processing, as well as the rest of the distribution.

These byproducts can be reprocessed to become valuable products and have high economic value. The type of product that will be produced will determine the technology that will be chosen in processing it. Some examples of the utilization of byproducts from fishery products are handicrafts (accessories from fish scales), fish meal, gelatin from fish, fish oil, fermented products, chips and fish crackers, organic fertilizer, and Biogas. 
Biogas consists of methane, carbon dioxide, Nitrogen, hydrogen sulfide, and oxygen. In Indonesia, this biogas energy source comes from the remains of animal manure, such as cows, sheep, poultry, pigs, horses, geese, pigeons, elephants, and remains from abattoirs and processing fishery products. In determining the potential of Biogas, it is influenced by the magnitude of the $\mathrm{C} / \mathrm{N}$ Ratio. This value will determine the amount of energy that can be produced from the Biogas. The value of $\mathrm{C}$ in organic compounds dramatically determines the amount of energy required for bacterial anaerobic processes. Apart from that, Nitrogen also plays an essential role because it determines the growth of bacteria. The balance of $\mathrm{C}$ and $\mathrm{N}$ values will play an important role in the formation of Biogas. The time for bacteria to carry out anaerobic processes on the organic matter is called "Retention Time". If the substance to be used as Biogas has good fermentation results, the retention time can take up to 6 months. The time is also influenced by environmental conditions and can occur for 30-60 days for the Tropics. Table 1 is a comparison of the C/N Ratio.

Table 1. C/N Ratio

\begin{tabular}{|l|c|c|c|c|}
\hline Animal Wastes & $\begin{array}{c}\text { C } \\
\% \text { Dry } \\
\text { Mass }\end{array}$ & $\begin{array}{c}\text { N } \\
\% \text { Dry } \\
\text { Mass }\end{array}$ & $\begin{array}{c}\text { C/N- } \\
\text { Ratio }\end{array}$ & $\begin{array}{c}\text { Moisture } \\
\text { Content of } \\
\text { Fresh Material }\end{array}$ \\
\hline Cow manure & 30 & 1.66 & 18 & $80-85$ \\
\hline Sheep manure & 83.6 & 3.80 & 22 & $75-80$ \\
\hline Poultry manure & 87.5 & 6.55 & 14 & $70-80$ \\
\hline Pig manure & 76 & 3.80 & 20 & $75-80$ \\
\hline Horse dung & 33.4 & 2.30 & 15 & $80-85$ \\
\hline $\begin{array}{l}\text { Elephant } \\
\text { manure }\end{array}$ & 60.0 & 1.30 & 46 & $70-85$ \\
\hline Slaughter waste & 64.0 & 8.0 & 8 & $55-75$ \\
\hline Fish waste & 56.0 & 7.0 & 8 & $55-75$ \\
\hline
\end{tabular}

Utilization of these materials as a source of biogas energy can provide several benefits, such as reducing the use of fossil energy, increasing the income of farmers and fishers, and increasing employment opportunities. Figure 1 is a form of the biogas power plant. In addition, biogas production has a significant impact on producing neutral carbon dioxide, which can overcome greenhouse gas emissions and simultaneously reduce air pollution well.

Data from the Ministry of Maritime Affairs and Fisheries in 2018, the production of small-medium large micro-scale fish processing units reached $6,181,997.48$ tons. These products are spread across 34 provinces in Indonesia. Table 2 is data on the results of processing unit production in Indonesia in 2018.

Table 3 below is the calculation of the $\mathrm{C} / \mathrm{N}$ Ratio on the effects of fishery processing from all MicroMacro Processing Units. The assumption is that $10 \%$ of the processing results are used for Biogas with a size of $5000 \mathrm{~m}^{3}$.
Table 2. Production of Indonesian Processing Units in 2018

\begin{tabular}{|c|c|c|}
\hline Province & $\begin{array}{l}\text { Production Processing } \\
\text { Unit (Tons) Small-Micro }\end{array}$ & $\begin{array}{l}\text { Medium- } \\
\text { Large }\end{array}$ \\
\hline $\begin{array}{l}\text { Nangroe Aceh } \\
\text { Darussalam }\end{array}$ & 114,904 & 9,668 \\
\hline Bali & 26,830 & 112,048 \\
\hline Banten & 89,525 & 34,872 \\
\hline Bengkulu & 26,160 & 0 \\
\hline DI Yogyakarta & 16,013 & 0 \\
\hline DKI Jakarta & 160,604 & 110,842 \\
\hline Gorontalo & 15,084 & 13,409 \\
\hline Jambi & 53,359 & 0 \\
\hline West Java & 409,858 & 103,531 \\
\hline Central Java & 848,485 & 168,860 \\
\hline East Java & 877,694 & 339,305 \\
\hline West Kalimantan & 94,345 & 22,947 \\
\hline South Kalimantan & 184,054 & 20,668 \\
\hline $\begin{array}{l}\text { Central } \\
\text { Kalimantan }\end{array}$ & 88,139 & 1,870 \\
\hline East Kalimantan & 65,543 & 11,854 \\
\hline North Kalimantan & 47,551 & 24,315 \\
\hline $\begin{array}{l}\text { Bangka Belitung } \\
\text { Island }\end{array}$ & 78,079 & 20,575 \\
\hline Riau Island & 64,978 & 12,649 \\
\hline Lampung & 156,708 & 38,487 \\
\hline Maluku & 69,785 & 32,113 \\
\hline North Maluku & 22,517 & 8,992 \\
\hline $\begin{array}{l}\text { West Nusa } \\
\text { Tenggara }\end{array}$ & 47,398 & 5,611 \\
\hline $\begin{array}{l}\text { East Nusa } \\
\text { Tenggara }\end{array}$ & 51,252 & 49,904 \\
\hline Papua & 60,681 & 2,891 \\
\hline West Papua & 39,008 & 30,020 \\
\hline Riau & 104,216 & 1,870 \\
\hline West Sulawesi & 31,764 & 0 \\
\hline South Sulawesi & 95,161 & 120,553 \\
\hline Central Sulawesi & 76,586 & 18,704 \\
\hline $\begin{array}{l}\text { Southeast } \\
\text { Sulawesi }\end{array}$ & 85,781 & 24,631 \\
\hline North Sulawesi & 15,874 & 116,612 \\
\hline West Sumatera & 101,896 & 3,741 \\
\hline South Sumatera & 101,323 & 10,057 \\
\hline North Sumatera & 276,305 & 112,938 \\
\hline Total & $4,597,460$ & $1,584,537$ \\
\hline
\end{tabular}

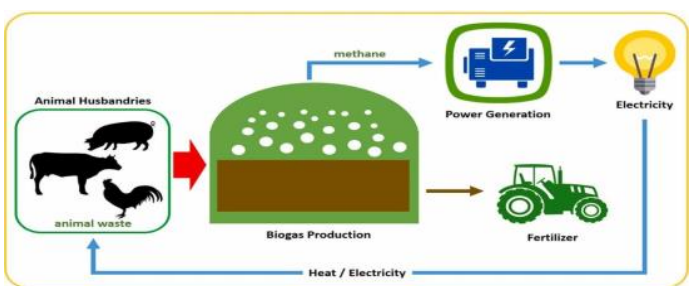

Figure 1 Biogas Production as Renewable Energy

Table 3. C/N Ratio of Fish Waste

\begin{tabular}{|c|c|c|c|}
\hline $\begin{array}{l}\text { Organic } \\
\text { Material }\end{array}$ & $\begin{array}{c}\text { Quantity } \\
\text { (Dry Mass) }\end{array}$ & $\begin{array}{l}\text { C-Content } \\
\text { (\% and } \mathrm{kg} \text { ) }\end{array}$ & $\begin{array}{l}\mathrm{N} \text {-Content } \\
(\% \text { and } \mathrm{kg})\end{array}$ \\
\hline $\begin{array}{l}\text { Fish } \\
\text { Waste }\end{array}$ & $\begin{array}{c}618,199,748.20 \\
\mathrm{~kg}\end{array}$ & $\begin{array}{c}56 \%= \\
346,191,858.99 \\
k g\end{array}$ & $\begin{array}{c}7 \%= \\
43,273,982.37 \\
\mathrm{~kg}\end{array}$ \\
\hline
\end{tabular}




\begin{tabular}{|l|l|l|l|}
\hline $\begin{array}{l}\text { Total per } \\
\text { day }\end{array}$ & $94,847,084.66 \mathrm{~kg}$ & $118,558.86 \mathrm{~kg}$ \\
\hline
\end{tabular}

Total Processing Unit Yield $=6,181,997.48$ Tons per year

$10 \%$ Remaining Processing Results $=618,199,748.20$

$\mathrm{kg}$ per year Average per day = 1,693,697.94 kg per day

$$
\begin{aligned}
\mathrm{C} / \mathrm{N} & =94,847,084.66 \mathrm{~kg} / 118,558.86 \mathrm{~kg} \\
& =8
\end{aligned}
$$

Amount of Biogas that can be produced $=$ Total TS (kg) x Gas Production $\left(\mathrm{m}^{3}\right)$

$$
\begin{aligned}
& =1,693,697.94 \mathrm{~kg} \times 5000 \mathrm{~m}^{3} \\
& =8,468,489,700 \mathrm{~m}^{3} \text { per day } \\
& =254,054,691,000 \mathrm{~m}^{3} \text { per month }
\end{aligned}
$$

The amount of electrical energy that can be generated

$$
\begin{aligned}
& =8,468,489,700 \mathrm{~m}^{3} \times 6.1 \mathrm{kWh} \\
& =51,657,787,170 \mathrm{kWh} \\
& =51.66 \mathrm{MWh} \text { per day } \\
& =1549.73 \mathrm{MWh} \text { per month }
\end{aligned}
$$

\section{CONCLUSION}

Utilization of the remaining processing results from marine and fishery products is estimated to have a biogas energy potential of $51.66 \mathrm{MWh}$ per day or 1,549.73 MWh per month. This energy allows it to be used as a power plant for coastal areas. This electrical energy can certainly help coastal communities support the need for electrical energy and indirectly reduce the use of fossil energy, which is not good for the environment.

Utilization of this biogas energy source requires supporting equipment in the form of a power plant scattered in several places. The participation of the Government and several stakeholders is very much required in supporting this potential. This utilization indirectly supports one of the Government's policies in using clean energy

\section{ACKNOWLEDGMENTS}

Thank you to the Ministry of Marine Affairs and Fisheries Republic of Indonesia and Marine and Fisheries Polytechnic of Kupang for all the support so that this research can be completed properly.

\section{REFERENCES}

[1] A.I. Burhannudin, The Sleeping Giant, the Potential and Problems of the Ocean, Brilian International, Surabaya, 2011.
[2] A.I. Burhannudin and H.M.N. Nessa Introduction to Marine and Fisheries, Deepublish, Yogyakarta, 2018.

[3] Minister of Maritime Affairs and Fisheries Regulation Number 92020 concerning Fisheries Management Areas of the Republic of Indonesia in Inland Waters.

[4] Subdirectorate of Fishery Statistics Statistics of Fishery Establishment 2018, BPSStatistics Indonesia, Jakarta, 2019.

[5] Ministry of Marine Affairs and Fisheries Republic of Indonesia, Marine and Fisheries in Numbers, Center for Data, Statistics and Information, Jakarta, 2018.

[6] I. Govender, G. A. Thopil, and R. Inglesi-Lotz, Financial and Economic Appraisal of a Biogas to Electricity Project, Journal of Cleaner Production 214, 2019, p 154-165. DOI: https://doi.org/10.1016/j.jclepro.2018.12.290

[7] D. Botkin and E. Keller, Enviromental ScienceEarth as a Living Planet, Jhon Willey \& Son Inc Canada, 1995.

[8] A.R. Picos-Benítez, J.M. Peralta-Hernández, J.D. López-Hincapié, and A. Rodríguez-García, Biogas Production from Saline Wastewater of the Evisceration Process of the Fish Processing Industry, Journal of Water Process Engineering, 2019, $32 \quad 100933 . \quad$ DOI: https://doi.org/10.1016/j.jwpe.2019.100933

[9] Bishop, L. Paul, Marine Pollution and Its Control, McGraw Hill Book Company, United State of America, 1983.

[10] State Ministry of Environment (Kementerian Lingkungan Hidup), From Crisis to Sustainability. Paving The Way for Sutainable Development in Indonesia: Overview of The Implementation of Agenda 21, State Ministry of Environment, Jakarta, 2002.

[11] T.G. Miller, Enviromental Science: Working with The Earth, $10^{\text {th }}$ Editon. International Student Edition Thomson Learning, Inc, 2004.

[12] F. Bücker, M. Marder, M.R. Peiter, D.N. Lehn, V.M. Esquerdo, L.A. de Almeida Pinto, and O. Konrad, Fish Waste: An Efficient Alternative to Biogas and Methane Production in an Anaerobic Mono-Digestion System, Renewable Energy 2020, 147 p. 798-805. DOI: https://doi.org/10.1016/j.renene.2019.08.140

[13] G.K Kafle, and S.H. Kim, Evaluation of The Biogas Productivity Potential of Fish Waste: A 
Lab Scale Batch Study, Journal of Biosystems Engineering, 2012, Vol. 37 (5) p. 302-313. DOI: https://doi.org/10.5307/JBE.2012.37.5.302

[14] B. Salam, M. Islam, and M.T. Rahman, Biogas from Anaerobic Digestion of Fish Waste, In Proceedings of the International Conference on Mechanical Engineering, 2009, Vol. 26 p. 1-3.

[15] Regulation of the Minister of Energy and Mineral Resources Regulation of the Minister of Energy and Mineral Resources concerning the Purchase of Electricity by PT Perusahaan Listrik Negara (Persero) from Municipal Waste-Based Power Plants, 2015.

[16] D. Notosudjono, D. Suhendi, and B.D. Ramadhon, Evaluation Study of Waste Materials for Renewable Energy Through 3R Model in Bogor City, in 2017 4th International Conference on Electrical Engineering, Computer Science and Informatics (EECSI), 2017, p. 1-4 IEEE. DOI: 10.1109/EECSI.2017.8239144

[17] I.G.M.N. Desnanjaya, I.B.A.I. Iswara, A.A. G. Ekayana, P.P Santika, and I.N.B. Hartawan, Automatic High Speed Photography Based Microcontroller, In Journal of Physics: Conference Series, 2020, Vol. 1469 No. 1 p 012096. DOI: https://doi.org/10.1088/17426596/1469/1/012096

[18] I.M.A. Nugraha, I. G.M.N. Desnanjaya, I. W.D. Pranata, and W. Harianto, Stability Data Xbee S2b Zigbee Communication on Arduino Based Sumo Robot, Journal of Robotics and Control (JRC), 2021, 2(3) p. 153-160. DOI: https://doi.org/10.18196/jrc.2370

[19] I.G.M.N. Desnanjaya and I.G.I Sudipa, The Control System of Kulkul Bali Based on Microcontroller, In 2019 5th International Conference on New Media Studies (CONMEDIA, 2019, p 244-250 IEEE. DOI: 10.1109/CONMEDIA46929.2019.8981841

[20] I.G.M.N Desnanjaya and I.M.A. Nugraha, Portable Waste Capacity Detection System Based on Microcontroller and Website, In Journal of Physics: Conference Series, 2021, Vol. 1810 No. 1 p 012001. DOI: https://doi.org/10.1088/17426596/1810/1/012001 